\title{
Bearers of Memory: Photo Albums as Sources of Historical Study in Palestine
}

\author{
Issam Nassar
}

This chapter can be generally described as an attempt to engage with three themes that have been pushed to the margins in the study of the history of photography. The first of these themes is the study of the photographic production of, and by, the Palestinians. Although in the recent years, a growing number of studies have come to light regarding certain native Palestinian photographers, they remain marginal if looked at in comparison with studies of the photographies of Europe or its colonial expansions abroad. This is partly due to the fact that all non-European histories of photographies have been relegated to inferior status, and never seriously considered when studying what is deemed to be the history of the practice. Suffice to remember that when studies appear about photography in the majority world, to use the concept introduced by Shahidul Alam, ${ }^{1}$ they do not appear with titles that places them within the general history of photography, instead with hyphenated titles that connects them with the specific country or region which they depict, such as Indian photography, Palestinian, Egyptian, Ottoman, etc. But books on French, British or American photographies usually appear with titles that places them into the larger history of the discipline. Furthermore, because the particular history of Palestine has become a contested subject due to its colonisation and the uprooting of its people, very little attention is ever given to its photographic history outside the narrow circle of Palestinians and a few other academic specialists.

The second theme with which this chapter deals, that has also been pushed to the margins, is that of the study of the photographic album as a compilation of images fashioned together to produce certain visual narratives. For albums are, after all, not only containers that preserve individual photographs, but

1 "Majority world" is the term popularised by the Shahidul Alam as an alternative to the often used "third World." See Maia Hibbett, "Free Shahidul Alam, the Photographer of the 'Majority World' in The Nation (August 24, 2018): https://www.thenation.com/article/archive/free -shahidul-alam-the-photographer-of-the-majority-world/, accessed November 9, 2020. 
pictorial narratives organised by their owners to tell stories about their own lives and adventures.

The third of the marginalised themes relates to the fact that vernacular photography is rarely considered as a subject worthy of serious study in contrast to professional or artistic work. Albums, more often than not, are composed of pictures that belong to this kind of photography, even if more professional images can also be found within their leaves.

The study at hand is, therefore, concerned with both the attempt to reclaim Palestinian life in Palestine and to interrogate the various possibilities in which albums of vernacular photographs could enable us to further our knowledge of that life. Of course, a short chapter such as this, cannot cover all aspects of the subject, but the hope is that it will be a starting point for further studies. This essay, therefore, will limit itself to examining three Palestinian albums from the first half of the twentieth century, before Palestine was removed from the map as a country and its people were deemed illegitimate Arab refugees.

The examined albums constitute three different types of compilations, not merely due to the differences in ways of collecting, but also in the fact that they were put together by very different kinds of individuals, with different photographic and social intentions. A person who saw himself as the storyteller of Jerusalem and its historian, Wāṣif Jawhariyya, produced the first of the albums under study. The second, crafted by an upper-class woman named Julia Luci, was clearly intended to narrate - whether intentionally or not - the highlights in her life and that of her family. A playful young athlete named George Mushabek produced the third, in which he documented a very specific event, that of his trip to attend the Olympics in $1936 .{ }^{2}$ While Jawhariyya collected images from professional photographers that were often given to him by friends and dignitaries, Mushabek's photographs were snapshots taken with the camera of an amateur traveller. At the same time, the album of Luci was compiled largely from studio portraits in which she or a relative of hers appeared in front of the camera in a setting that was carefully planned. Still, we find exceptions in all of the albums that do not conform to the rest of the included photographs. The albums, therefore, can be said to represent both the public and the private spheres. The three albums were rescued either through the fact that their owners took them on their journeys to exile in 1948, or were reclaimed from where they were left after the occupation of the rest of Palestine in 1967. All three albums were put together in the part of Jerusalem that fell to Israeli control in 1948 during the Palestinian Nakba.

2 The Albums of Wāșif Jawhariyya are kept in the archives of the Institute for Palestine Studies in Beirut and the other two are with relatives of the two original owners of the albums. 
Before delving into a discussion of the albums at hand, I would like to state three elementary observations that are of great significance for studying pictures. The first is that photographs are never static objects, even if they are physically so. Rather, they are dynamic artifacts that continue to acquire new meanings socially and historically, as Elizabeth Edwards argues. In her words, photographs are 'not merely passive and inert entities to which things happen and things are done', rather, they 'remain socially and historically active' shifting between different contexts and open to 'multiple performances and the making of multiple meanings. ${ }^{3}$ Viewing the photographs affixed in the albums, a century later and in a dramatically different historical and social circumstance, one cannot escape imposing new meanings and removing the intimacy which the people in the photograph and the owners of the albums must have had with each and every image.

It is through such a process that we neutralise the images at hand and rub out of them any temporal, personal attachments that led those particular photographs to be included in the albums. In a sense, we exercise our own power over the photos, disregarding the power of those who appear in the photographs. One example that could illustrate this point comes from the album of Wāṣif Jawhariyya, which he devoted to the late Ottoman period in Jerusalem. In the album, Wāṣif included a photograph of the infamous Jamāl Pāshā, the ruler of Bilād al-Shām during the Great War. The Pasha was such a brutal authoritarian figure, at least in the eyes of his Syrian subjects, that he was given the name al-Safāh, meaning the blood shedder. It is very likely that a person living in Jerusalem or Damascus during the Pasha's reign would never have dared to look Jamal in the eyes. But now, a century later, I am able to fix my gaze on his eyes as they appear in the photograph for as long as I want, totally free from any feeling of fear.

The second observation that I would like to make relating to the nature of family pictures is in line with Marianne Hirsch's observation that 'recognizing an image as familial elicits a specific kind of readerly or spectorial look, an affiiative look through which we can be sutured into the image and through which we adopt into our own familial narrative.' ${ }^{4}$ In other words, the familial gaze that she is referring to relates to the sense of familiarity that a viewer has when looking at family pictures of other people that bear some resemblance to their own family photographs. In a sense, gazing at another family's photograph - be it a

3 Elizabeth Edwards, Raw Histories: Photographs, Anthropology and Museums (Oxford: Berg., 2001), 13-14. Also cited in Nawal Musleh-Motut, "From Palestine to the Canadian Diaspora: The Multiple Social Biographies of the Musleh Family's Photographic Archive," Middle East Journal of Culture and Communication 8 (2015): 308.

4 Marianne Hirsch, Family Frames: Photography, Narrative, and Postmemory (Cambridge: Harvard University Press, 1997), 93. 
portrait or a snapshot - we project familiarity from our own family into the one in the picture, recognising those present in it as a family and assigning roles to them within the household structure based on the semblance with our own.

The third observation I would like to highlight relates to the nature of photography albums, treated in this chapter as primarily narratives that recount a story authored by the people organising them. It is worth remembering that even if the owner of each of the albums desired to present a certain tale through the pictures included and the sequence in which they are presented, the materiality of the album itself often dictates certain elements relevant to the story being told. By that I mean the album, as a commercial product sold in the market, already limits the space available for the photographs and their numbers on each page. Sometimes, the albums have certain designs that might impose certain additional meanings and artistic touches that could potentially intertwine with the narrative being told. One example from the three albums under study is Mushabek's, who used an album designed and sold at the Olympics and ornamented with the logo of the games, scenery from the host country and even a picture of the leader of that country.

\section{$1 \quad$ Palestinian Worlds}

\subsection{WäșifJawhariyya}

Moving on to the albums themselves, the subject of this study, we will start with one of the seven albums of Wāṣif Jawhariyya. The album in question is that which Wāṣif devoted to Ottoman Jerusalem and numbered album one in his collection. The album is divided thematically, when it comes to the portraits, and chronologically, when the photographs are of events. It centred on life in the city, including the political changes that were taking place in each period. Wāșif kept a separate notebook for each of the albums, in which he described every picture included.

The album is filled with professional photographs of the leaders and elites in Jerusalem during the last two decades of Ottoman rule over Palestine. As an archive, the album is unique in terms of the images it contains. Interestingly enough, Wāṣif fashioned it as if it was an official album produced by an Ottoman authority in the city. He even states on the first page that he dedicates it to both the sultan and the governor of the city, both of whom were no longer in position, or even alive, when the album was constructed in 1924.

As peculiar as that may seem, it does constitute an indication of Jawhariyya intention in collecting the photographs and fashioning them into an album. For there is no chance whatsoever that he had any kind of relations 


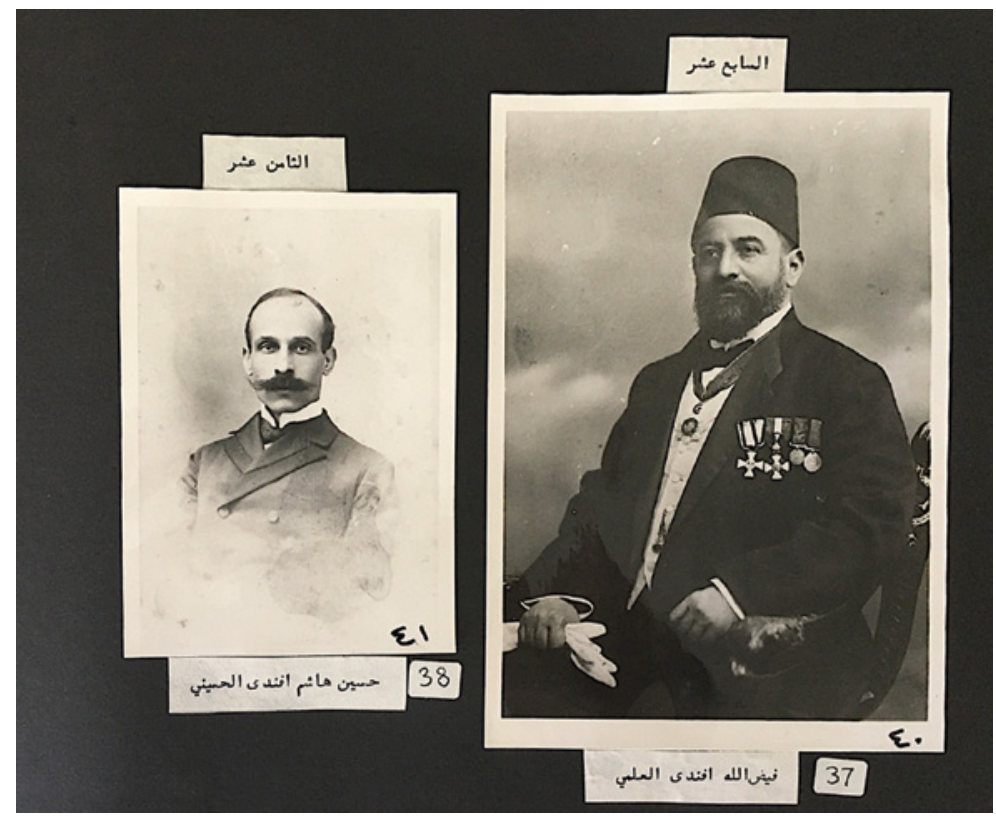

FIGURE 5.1 A page from the album showing the mayors of Jerusalem. Album 1, Wāṣif Jawhariyya IMAGE COURTESY OF THE INSTITUTE FOR PALESTINE STUDIES

with the sultan, nor that the sultan would have had the opportunity to ever see the albums. In addition, it is clearly a dedication written after the fact, with the intent of giving merit to the album as a public work as if it was a published book. Moreover, the specific sultan to whom he dedicated the album was removed from power in 1909, when Jawhariyya himself would have been no more than a teenager. In addition, in his own memoirs Jawhariyya showed disapproval, if not outright animosity, towards this specific sultan. The dedication read as follows:

\section{Sulțān 'Abd al-'Azīz}

I adorn this book with the logo of the Ottoman state [...] his royal majesty Sultān 'Abd al-'Azīz, one of the great kings of the Ottoman State who was followed in the high position by his brother Sultan Abdul Hamid. And with a photo of his Excellency Ra'uf Pāshā, the mutașarrif of Jerusalem.

As in the case of the sultan, Ra'uf Pāshā was not the governor of the city at the time Wāșif put together this particular album. It is more likely that by not making the dedications to the last sovereign sultan of the empire, but to two 


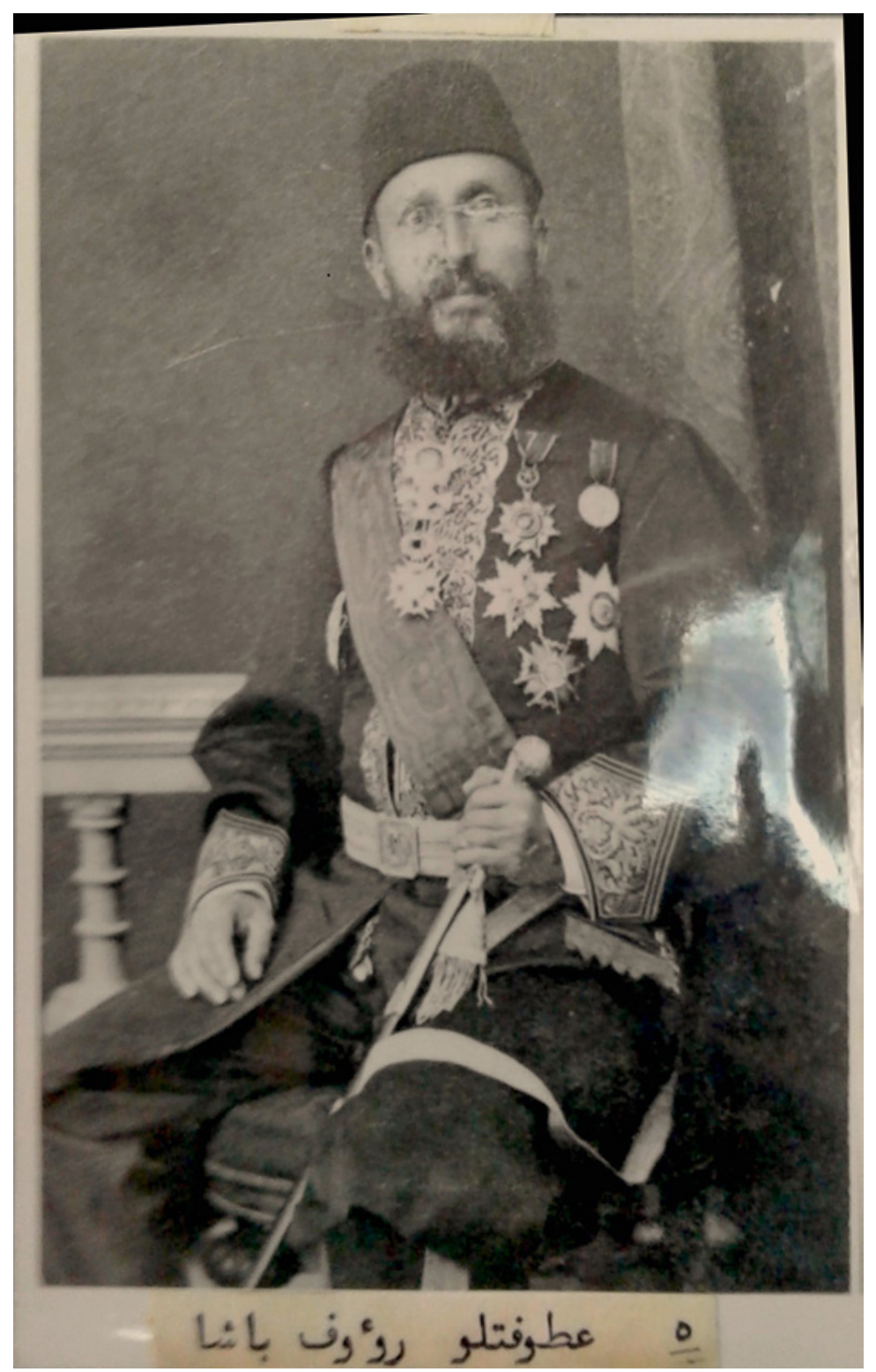

FIGURE 5.2 A photograph of Ottoman mutașarrif Ra'uf Pāshā. Album 1, Wāṣif Jawhariyya

IMAGE COURTESY OF THE INSTITUTE FOR PALESTINE STUDIES 
previous ones, as well as to a previous governor, Jawharriyya was echoing his father's admiration of the specific regime that was overthrown and replaced by one that was significantly different and perhaps had more elements of Turkish anti-Arab xenophobia than its predecessor. Jaryas Jawharriyya, the father of Wāṣif, was a judge in the Sharīa court in Jerusalem, despite being a Christian subject of the state, during the period of both Sultān 'Abd al-Hamìd and governor Ra'uf Pāshā. ${ }^{5}$ Hence, the dedication could be read more as honouring his own father than reflecting his own politics in which, based on his published memoirs, he appears to have been an opponent of the Hamidian regime. Still, there is another possibility that could explain such a dedication: namely that the compiler of the album aimed at reflecting the dominant discourse relating to the periods he was documenting. A sign of such an act can be seen in the photographs of the other authority figures that he included in his albums, such as Jamal Pasha, the head of the Fourth Ottoman Army in Palestine during the Great War, to whom he often referred in his memoirs as 'the blood shedder,' even as he was proudly announcing that he saw or encountered him at some point. The same is true of portraits of British governors and High Commissioners, whose pictures he included in the other albums in a rather celebratory fashion, appearing with their wives or entourages, despite his clear opposition to them in his memoirs as enablers of the Zionist colonisation of Palestine. ${ }^{6}$ Jawharriyya, like many Palestinians, celebrated the end of Ottoman rule in Palestine hoping that it would be a step towards Arab independence. Writing in his memoirs about the day Jerusalem fell to the British, he stated: ' $[w]$ e began to breathe relief and praised the Almighty for this blessing', adding 'little did we know at the time that this cursed occupation was in fact a curse for our dear country' ${ }^{7}$

What is clear is that Jawharriyya fashioned his albums to reflect the historical record more than to display his personal feelings or the ties he might have had with the leaders whose photographs adorned his albums. In the captions, the notebooks that accompanied the albums as well as in his memoirs, Wāṣif often referred to his relationship to some of the individuals depicted. Was he trying to place himself, or his family, within the echelons of high society in the city?

5 For a more detailed account on Jaryas Jawhariyya see: Wasif Jawharriyyeh, The Storyteller of Jerusalem: The Life and Times of Wasif Jawhariyya, eds. Salim Tamari and Issam Nassar (Northampton, MA: Interlink Publishing Group, 2014), 10-12.

6 Jawharriyya's album 2 devoted to British rule in Palestine includes a large number of portraits of British officials.

7 The Storyteller of Jerusalem, 99. 


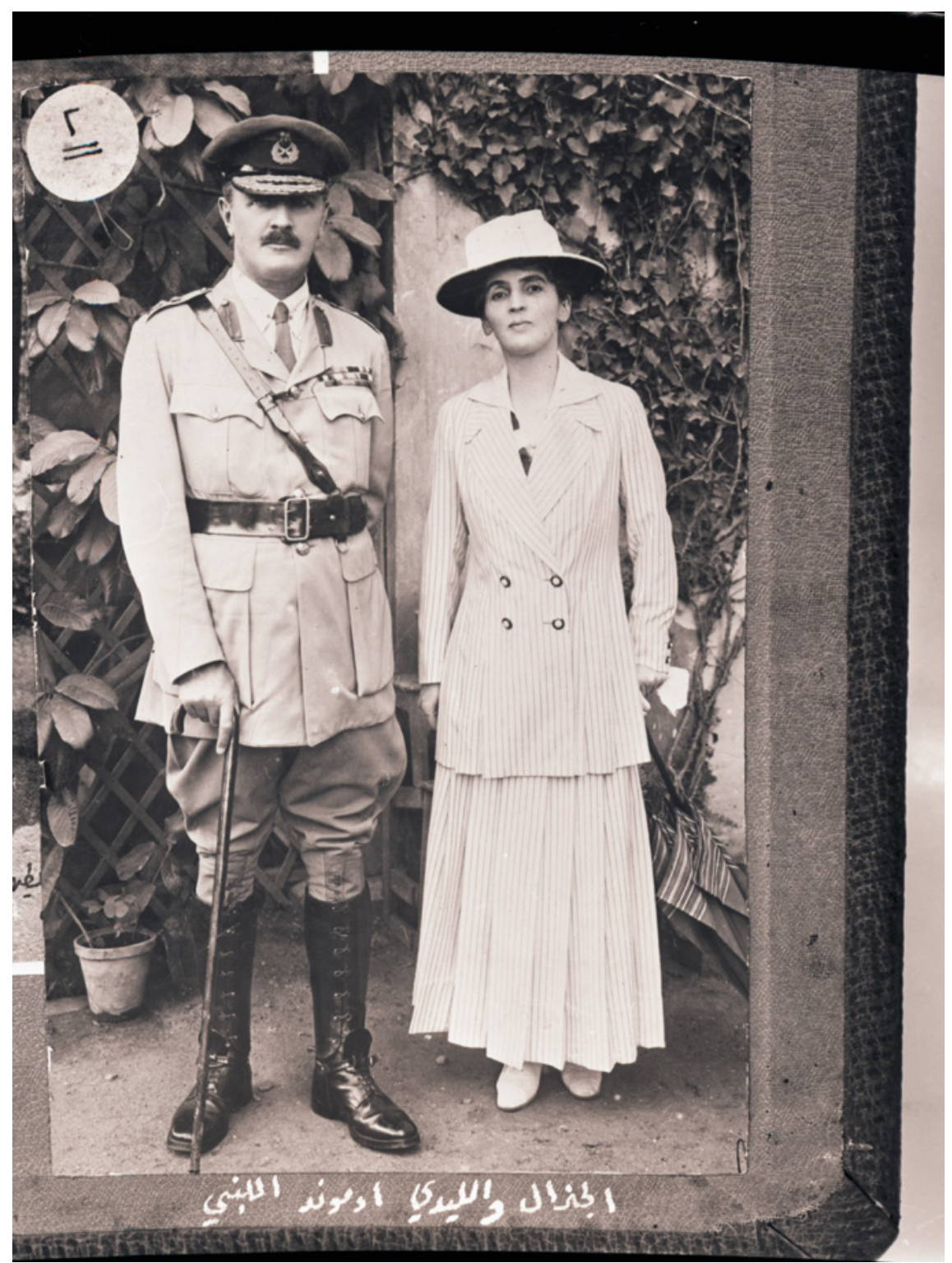

FIGURE 5.3 General and Lady Allenby in Jerusalem. Album 1, Wāșif Jawhariyya IMAGE COURTESY OF THE INSTITUTE FOR PALESTINE STUDIES 


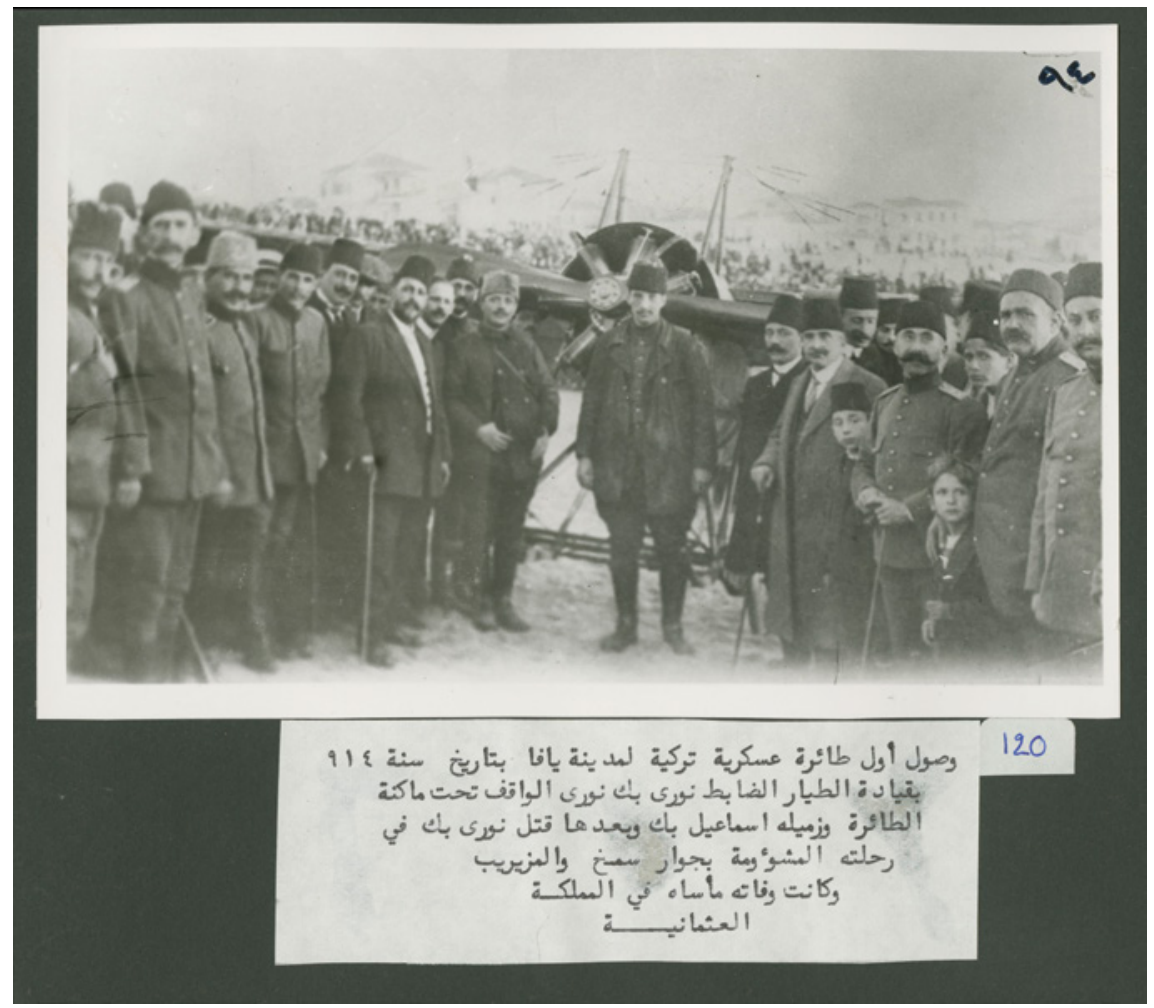

FIGURE 5.4 The Ottoman pilots in Jaffa. Album 1, Wāṣif Jawhariyya IMAGE COURTESY OF THE INSTITUTE FOR PALESTINE STUDIES

The answer to this question is in the affirmative for, in his notebooks, Wāṣif stated that he acquired many of the photographs (carte de visites) as gifts from the notables they depict. He inserted himself into the photographs as an eye witness to history, not through actually being one of the people depicted in the photographs, but through a narration that places him either in the vicinity of the events depicted or explains his relationship to those present in the pictures. Several examples can be provided to illustrate this point. They include his lengthy description of what he witnessed in 1914 when an Ottoman plane was due to land in Jerusalem. The plane never arrived as it crashed in northern Palestine on its way to the city, but Wāṣif described how the people were waiting in the sun for the arrival of the plane, and how some sold water or other drinks to make some money and cool off those waiting in the heat. He inserted a photograph of the plane and its crew before they departed from Jaffa and described the gloomy feelings that dominated the city upon receiving the news. 


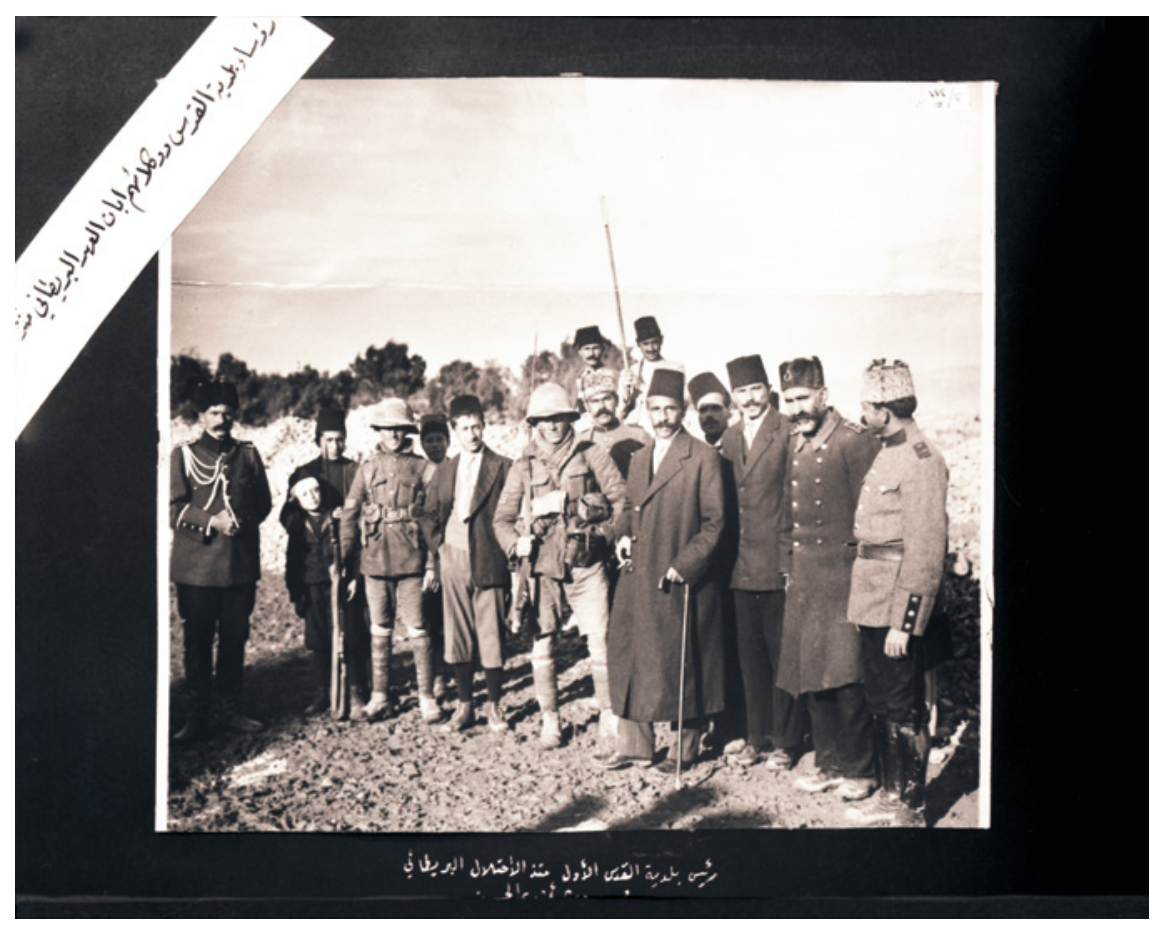

FIGURE 5.5 The surrender of Jerusalem. American Colony Photo Department. Album 1, Wāṣif Jawhariyya IMAGE COURTESY OF THE INSTITUTE FOR PALESTINE STUDIES

Another example relates to his narration of the last photograph in the album, the famous photograph showing the surrender of Jerusalem to the British forces on 9th December, 1917, in which the mayor of the city and his entourage posed with the white flag of surrender next to the two soldiers that they encountered on that day. Wāṣif named those appearing in the photograph, highlighting his personal or family relationship to them, ${ }^{8}$ and even made the

8 According to Wāṣif's memoirs those present in the photograph include: Tawfiq Muhammad Saleh al-Ḥusaynī; Ahmed Sharaf, police commissioner; Hajj Abdul-Qader al-Alami, police commissioner - lancers; Shamseddine, policeman; Amin Tahboub, policeman; Jawwad Bey bin Ismail Bey al-Husaynī, who was wearing short trousers; Burhan, son of the late Taher Bey al-Husaynī; and behind Husayn Bey, the white flag of surrender, held by Jamāl Pāshā's driver, a Lebanese man called Salim who was married to the sister of Hanna al-Lahham. The latter was standing by his side. Only two individuals were present from the other party (the British army). See WasifJawharriyyeh, The Storyteller of Jerusalem, 100. 
claim that the surrender flag was a bed sheet brought from his family's home in the Old City. ${ }^{9}$

This photograph, taken by Lars Larsson, a photographer from the American Colony group in Jerusalem, is a famous image that had already appeared in numerous publications with captions which usually highlighted the names of the two British officers. It constitutes a strong example of simultaneous, non-intersecting histories from which the people of the city are often left out, but Wāșif reverses that process completely. Not only does Jawharriyya fail to mention the names of the two officers and list the names of everyone else present, but he even describes in his caption what he was doing and where he was at the time of the event, despite his not being in the photograph, or even in the vicinity of the location in which it was shot. While it is possible to read Wāșif's description as inscribing the natives into the historical narrative, in my view it is more about placing himself individually within the historical context.

Sometimes, Jawharriyya is actually present in the image; a few photographs show Wāșif among a crowd - sometimes with his father or the mayor of Jerusalem - and in such cases he made sure to draw an arrow pointing to himself or, as in one case, to the location of his house in a panoramic view of Jerusalem.

The great figures that appeared in his albums always looked their best in portraits which gave them the aura of authority rather than in images that showed them behaving ruthlessly. Despite stating in his notebook that he acquired pictures from certain notables, in the album Wāșif does not provide information about the sources of each photograph or about its photographer. This stands in contrast to the careful documentation that accompanied his memoirs that were recently published, decades after his death.

\subsection{Julia Luci}

Julia Luci's album, in contrast to Jawharriyya's focus on the public sphere, constitutes a private archive of personal and familial life. The photos in the album are a combination of studio portraits of her and of her family and friends. But the album also includes snapshots of family events. Gisèle Freund pointed out that the emergence of photographic portraits corresponded historically 'with the rise of middle class and their increased social, political and economic

9 In her book Our Jerusalem, Bertha Spafford Vester claimed that the white flag came from the American Colony hospital. See Bertha Spafford Vester, Our Jerusalem (Garden City, N.Y., 1950), 255 . 
power. ${ }^{10}$ The portrait enabled the members of the middle class to visually affirm their social status. A Jerusalem-raised woman from rather humble origins, married to a Bethlehemite of similar background, Julia and her husband Jaryas migrated to Haiti early in their marriage, where they opened up a business venture that expanded in the late 1920 and the 1930s. After accumulating enough wealth in Haiti, the couple returned to Palestine and decided to settle in the upscale neighbourhood of Jerusalem, al-Baqa'a, where they built a house and opened various new business ventures. Among the different enterprises that they engaged in was a building of several storeys on Ben Yehuda street in the new part of the city.

The album visually reflects and affirms the new status of the couple as part of the social and economic elite, not unlike Jawharriyya's albums, albeit different in scope due to it belonging to the private sphere of the home. The first few pages of the album were devoted to portraits of the couple, individually and together, along with portraits of relatives - mostly on Julia's side. This can be an indication that the album was a project of Julia alone without much, or perhaps any, input from her husband. Still, it might also be an indication of who the potential viewers of the album would be. While the Bethlehemite husband's relatives remained living in their houses in one of the old quarters of Bethlehem, Julia's were moving into the new suburbs of Jerusalem and expanding their business ventures significantly. She was known for her Tuesday gatherings for women friends known as istiqba $\bar{a}$, or reception, when her friends from the neighbourhood would come and spend the entire afternoon visiting, and perhaps looking at the album which would have been placed on the coffee table in the middle of the guest room, as was the habit on middle class homes at the time. Her new social status was continuously asserted not only through the delicacies she offered her guests, but also through the images that appeared in the album. In her study of the construction of journals by Russian women, Gitta Hammarberg made the observation that a 'woman (and occasionally a man) was the owner, main reader, and addressee of an album; she determined who inscribed and read it, and her social context both produced it and was reproduced in it; she 'edited' it by erasure or commentary'.11 Julia's album illustrates Hammarberg's point clearly, as it was fashioned by her not only as its main 'reader', but as the addressee of the album as a

10 Gisèle Freund, 'Precursors of the photographic portrait', in The Nineteenth-Century Visual Cultural Reader, eds. Vanessa Schwartz and Jeannene Przyblyski (New York: Routledge Publication, 2004), 79 .

11 Gitta Hammarberg, "The First Russian Women's Journals and the Construction of the Reader," in Women in Russian Culture and Society, 1700-1825, eds. Wendy Rosslyn and Alessandra Tosi (New York: Palgrave McMillan, 2007), 84. 
woman of certain social class which is affirmed through each and every picture inside it as well as through its entirety as a journal of sort.

The social class that Julia belonged to was that of the new and aspiring bourgeoisie in Palestine of the period, not the old landed aristocracy. The new bourgeoisie class saw itself as part of the world of wealth and leisure based on accumulation not only of capital, but of material goods and the latest innovations coming from abroad. They distinguished themselves through their embrace of, and affinity with, the bourgeois European lifestyle and latest trends in consumption and leisureliness as well as their embrace of the new ideas that the Nahda, or Arab renaissance, thinkers were preaching. ${ }^{12}$ Producing a family album was perhaps a sign of belonging to the new class, as peasant women certainly did not produce such artifacts.

Among the studio portraits that appear in the album, we find several in which Julia, or one of her female friends, appear in traditional village dresses. The photograph below is perhaps the best among them technically. Although the photograph is signed by 'Paramount Photo, J. Solomon', we have no information on this particular photographer, though the name might suggest that the photographer was Jewish, not Arab. In it, Julia appears with her sister in-law, both dressed in embroidered thawb that recall those of the Ramallah peasantry, and perhaps of Bedouins from southern Palestine. Considering that Julia hailed from an urban Jerusalem family, and her sister in-law from a Bethlehemite one, the outfits reflect neither how they normally dressed, nor the traditional dresses of their hometowns. Such an image is in line with a tradition that existed in early local photography of Palestine, where studios had 'exotic' attire readily available for the benefit of the European tourists who wanted to appear in oriental dress, as the advertisement by Ḥannā Tūmāyān, below, clearly illustrates. Members of the upper classes in Palestine started to imitate the European visitors and sometimes had their pictures taken in the studio in traditional dresses, adopting, perhaps, the orientalist tradition as a sign of their difference from the rural or Bedouin population of Palestine. ${ }^{13}$ Taking a portrait in peasant dresses was perhaps their way of showing affinity with the western tradition and a statement that 'proved' their special social

\footnotetext{
12 Sherene Seikaly wrote an excellent study on the rise of the new bourgeois class in Palestinian society. See Sherene Seikaly, Men of Capital: Scarcity and Economy in Mandate Palestine (Stanford: Stanford University Press, 2016).

13 Perhaps the various self-portraits of the English photographer Francis Frith (1822-1898) dated 1857 provide good examples of such early European practice. Many of such images are available online. See: https://sites.hampshire.edu/reorient/works/frontispiece -portrait-of-turkish-summer-costume/ and https://commons.wikimedia.org/wiki/File: FrancisFrith.png.
} 


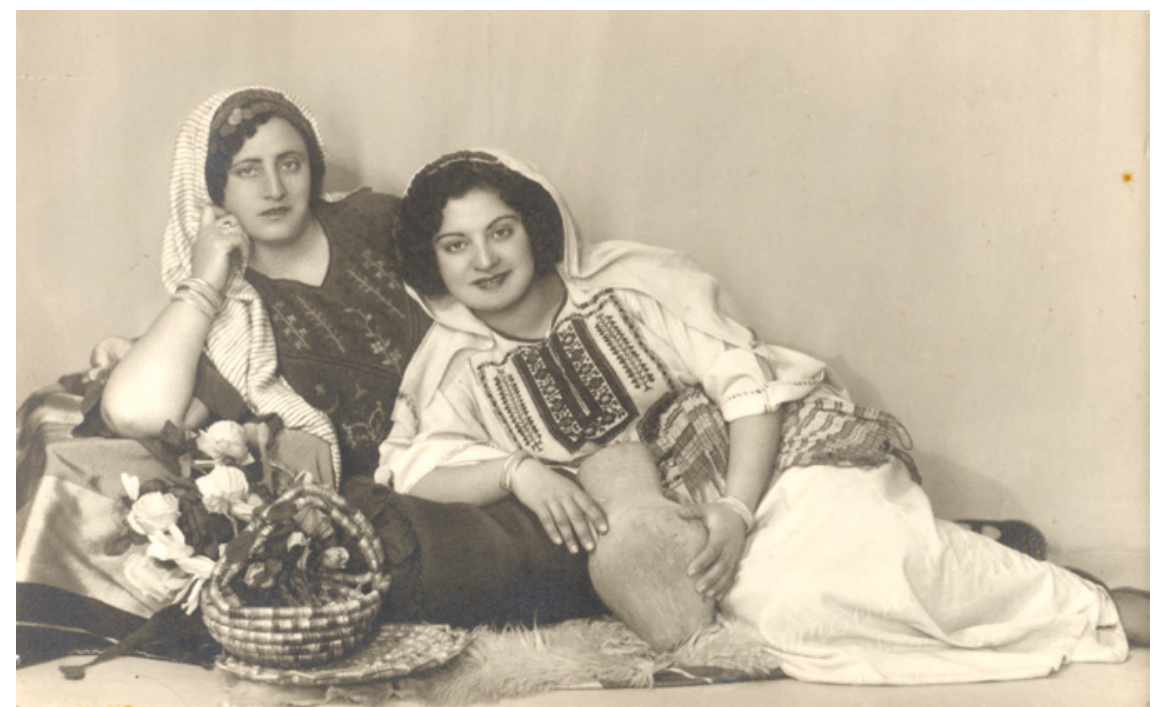

FIGURE 5.6 Julia and sister in-law. Julia Luci's album IMAGE COURTESY OF THE LUCI FAMILY

status in society. Still, we cannot fully dismiss the possibility that the picture of Julia and her sister in-law were also celebrating and showing pride in their Palestinian heritage as they both had enough distance from the peasantry that they see them and their attire as part of their own past.

The album also included studio photographs of child relatives seated on sheepskin rugs, sometimes in the nude - another trope popular at the time, especially among the nouveaux riches. Such images are interesting not only in showing the status to which the family of the child aspired, but also because they could relate to what Lacan called the mirror stage through which the child recognises him or herself as an independent person from the mother. ${ }^{14}$ An example of such images is that of her nephew, Sami, in a studio portrait on his first birthday sitting on a lambskin.

Among the photographs in the album, we also see pictures of the vacations Julia and her husband took to places in Lebanon and elsewhere. Pictures of the new houses built by her siblings in the same neighbourhood were also present, as well as photographs of the younger relatives taken to mark certain special occasions.

14 Jane Gallop, "Observation of a Mother," in The Familial Gaze, ed. Marianne Hirsch (Dartmouth: University Press of New England, 1999), 79. 


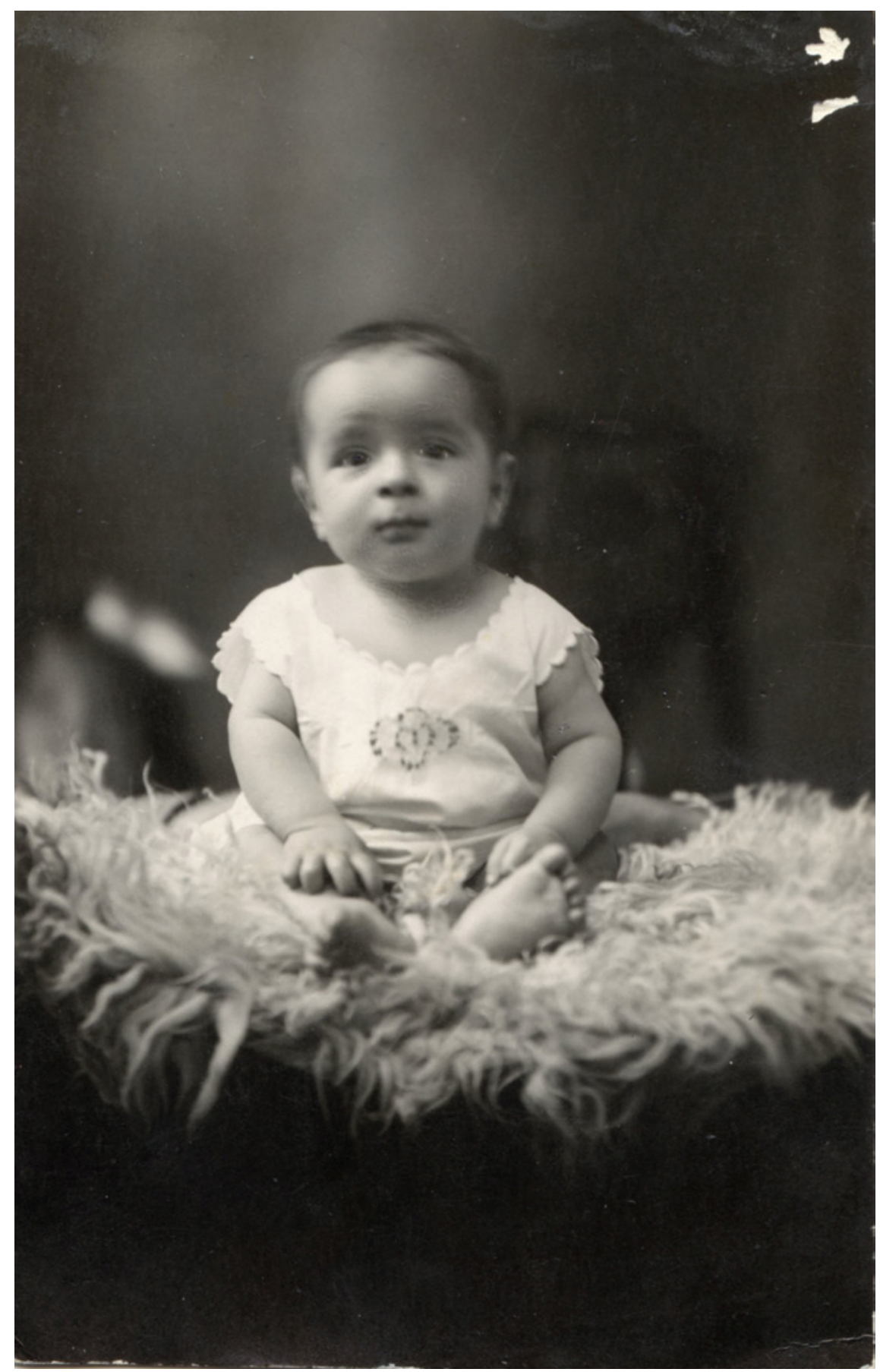

FIG URE 5.7 Julia's nephew Solieman Salti. Julia Luci's album IMAGE COURTESY OF THE LUCI FAMILY 


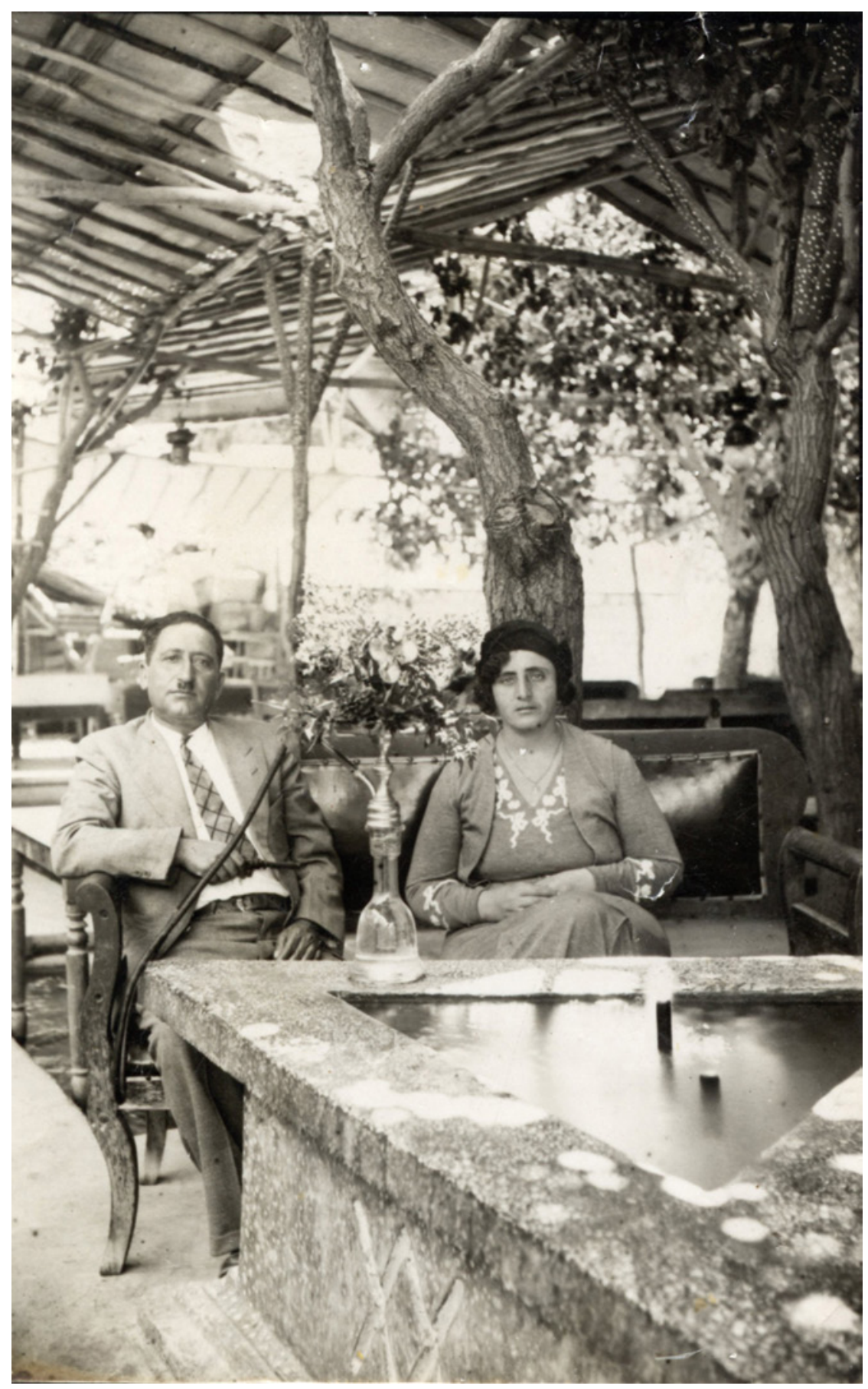

FIGURE 5.8 Julia and husband on vacation in Lebanon. Julia Luci's album IMAGE COURTESY OF THE LUCI FAMILY 
Luci's album largely represents the private life of her family, emphasising the highlights in her own life, including the trips she and her husband took, or the new house they built. However, what stands out is the very last picture of the album, in which the building her husband owned on Ben Yehuda street in Jerusalem is shown after its destruction as a result of a bomb placed by Palestinian fighters. The bombing was due to the fact that in the building there were offices of a Zionist organisation - not known to this author - and the street was the hub of Jewish economic activities. ${ }^{15}$

The fact that this was the last picture in the album is an indication, perhaps, of the burden of the trauma of loss, both financially as well as in social status, which must have weighed heavily on Julia Luci. Following her exile from Jerusalem, she and her husband lost their property and with it their social standing. Her husband passed away shortly after the Nakba while he was standing on a hill south of Jerusalem, trying to look at the part of the city where he once lived. Julia never added any pictures from the last three decades of her life after the destruction of Palestine in 1948. Sadly enough, the album in retrospect shows us now not where she once was, but who she once was. For us today, it evokes collective memories that might not be about what appears in it, but the life that was lost with the Nakba.

\subsection{George Mushabek}

The third album that this paper tackles is of a journey taken by five young friends from Jerusalem to attend the 1936 Olympics in Germany. The album belongs to George Mushabek, who also lived in the part of the city that fell to Zionist control in 1948. It documents the trip the five friends took from Jerusalem to Berlin by sea. Along with Mushabek, the other four; Ghabì and Raymūnd Dīb, Attāla Kidās and Frītz Marrūm, were also Jerusalemite, Christian member of the YMCA. ${ }^{16}$ The album itself is an item of memorabilia from the

15 The information about the Luci's ownership came from various oral interviews conducted with relatives on different dates. The bombing that occurred on February 22, 1948 is well documented and according to the Palestine Post of February 23, 1948, it took place in front of the Atlantic Hotel building, owned by an [unnamed] Christian Arab, possibly Luci. The hotel, according to a report by a British Palestine police source, housed the headquarters of the elite Palmach troops. See http://britishpalestinepolice.org.uk/polhist5o.html (accessed on October 20, 2020).

16 Special thanks to Mona Halaby for her help in identifying the individuals. It might be worth mentioning that Attallah Alexander "Ted" Kidess (1910-1999), was a leading figure in the Jerusalem YMCA as he served as its physical director. See San Charles Haddad, "Rise of the Reich in Mandate Palestine: The NSDAP, Jerusalem YMCA, and 'Participation' of Attallah Kidess in the 1936 Berlin Olympic Games," Journal of Olympic History 28, no. 2, 2020: 20-33. 


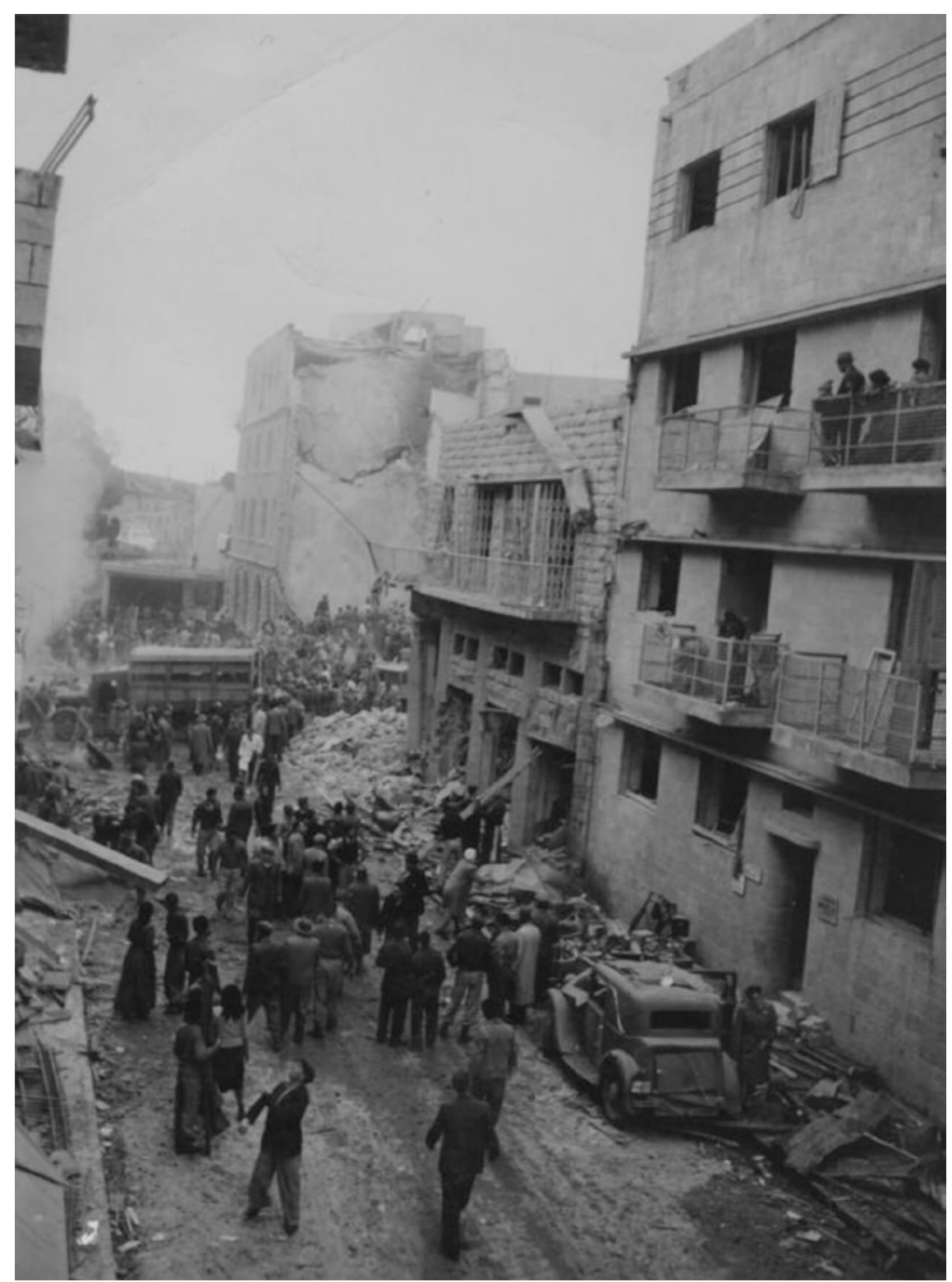

FIGURE 5.9 Bombing on BenYehuda St, 1948. Julia Luci's album IMAGE COURTESY OF THE LUCI FAMILY 


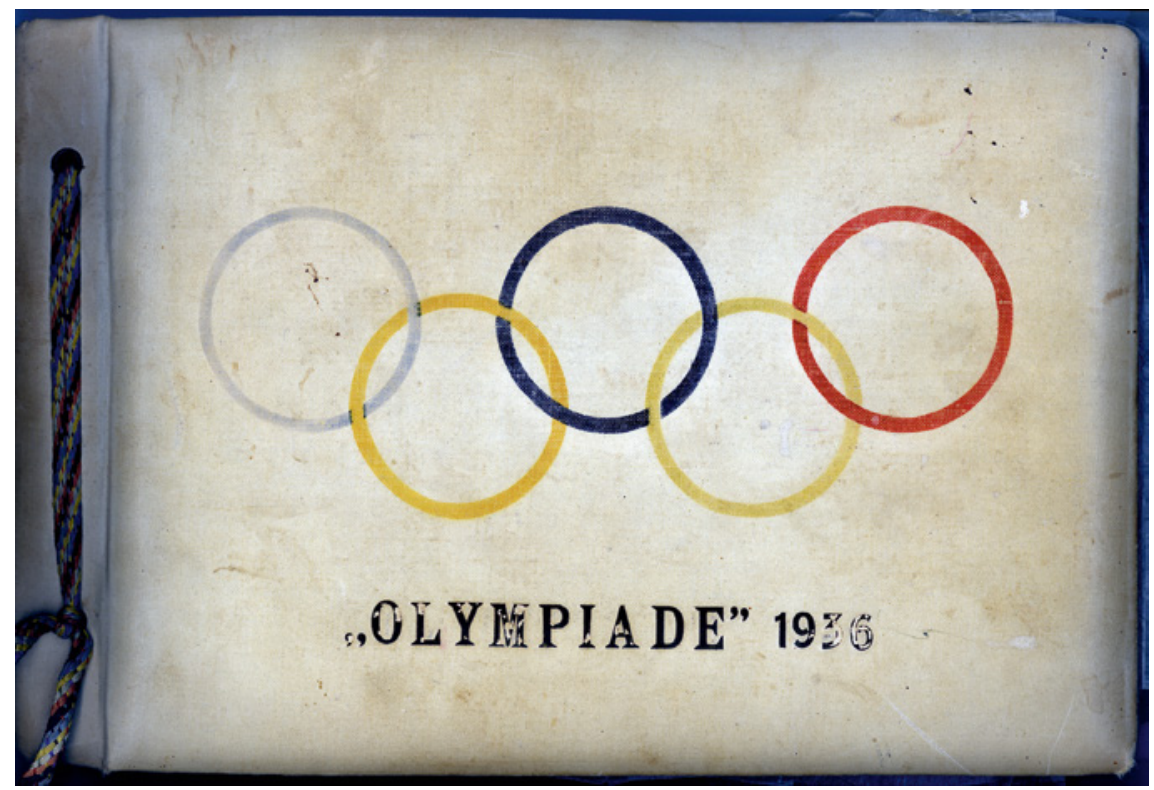

FIGURE 5.10 Cover of the album. Olympic Album, George Mushabek IMAGE COURTESY OF THE MUSHABEK FAMILY

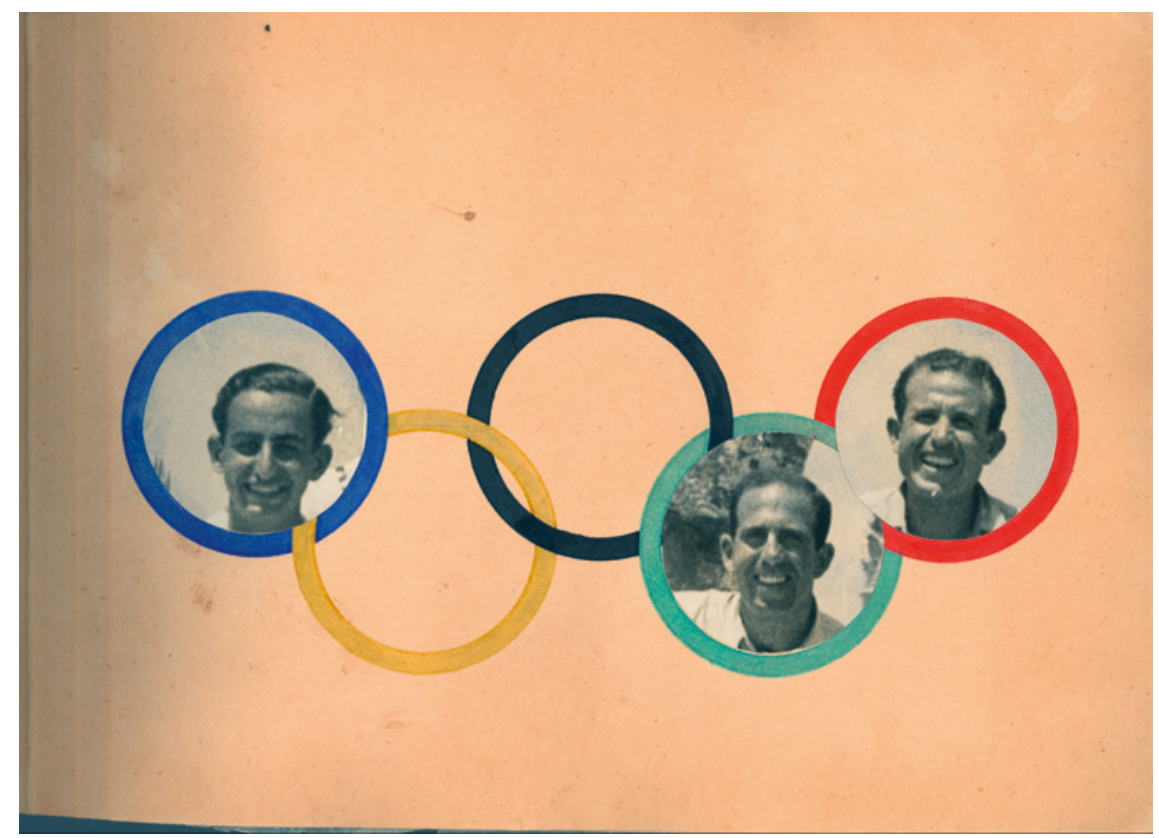

FIGURE 5.11 The inside cover of the album. Olympic Album, George Mushabek IMAGE COURTESY OF THE MUSHABEK FAMILY 
Olympics with the logo of the games on the cover and imprinted images within from the preparations for the games. The imprinted photographs include an aerial photograph of a stadium, a map of a stadium, views from Berlin, where the games were held, and a photograph of Adolf Hitler talking with members of the German team. On the inside cover of the album, Mushabek placed the faces of the five friends within the five circles of the Olympic logo, although two of the photographs have been lost.

The photographs in the album were taken using a handheld camera and could be classified as amateur snapshots, rather than professional photographs, and thus are more spontaneous and freer of the constrictions of the studio portraits seen in the previous two albums. The album is organised chronologically, detailing the journey of the five friends, their departure from Jerusalem through to their attendance at certain games during the Olympics. In this sense, the album is a visual travelogue of the trip. The return journey to Palestine was not included in the photographs. In this sense, it does resemble an inversion of European tour albums most famous since the end of the nineteenth century where Western tourists and pilgrim took one of Thomas Cook's excursions to the Orient including Greece, Palestine and Egypt.

Tourists also fashioned their albums in chronological order and included snapshots of themselves in front of the monuments and sites they visited. But unlike such albums, Mushabek's does not have captions, though at times a short description is inscribed directly on some photographs, giving a date and location. Unlike the European tourists, who often included a reference to some Biblical verse or another in their captions, no references to historical texts appear in our album. The five friends were on a fun trip, not on a pilgrimage. This fact becomes clear when we notice a complete lack of interest in the politics of the places they visited.

There is also no indication that the group had any interest in the politics of this particular Olympics, which came to be known as Hitler's Olympics by historians and politicians later on. Aside from the embedded picture of Hitler with the team that came with the album, there are no signs of Nazi influence of paraphernalia anywhere in the album - though the Nazi flag appears in some of the pictures of the streets of Berlin included in the album. In any case, although Zionist propaganda often made the Palestinians appear to be on the side of Hitler and the Nazis due to the visit of Palestine's Grand Mufti Hājj Amīn al- Husaynī to Berlin and his meeting with Hitler in November 1941, the general mood in Palestine at the time was wary of the rise of Hitler and what it might mean for the country as attested to in the various articles that appeared in the Arab newspapers at the time. Anticipating how Hitler's policy towards to the Jews would affect Palestine, the Jerusalem based al-Jamā'a al-Islāmìya newspaper warned as early as March 1933 that: 


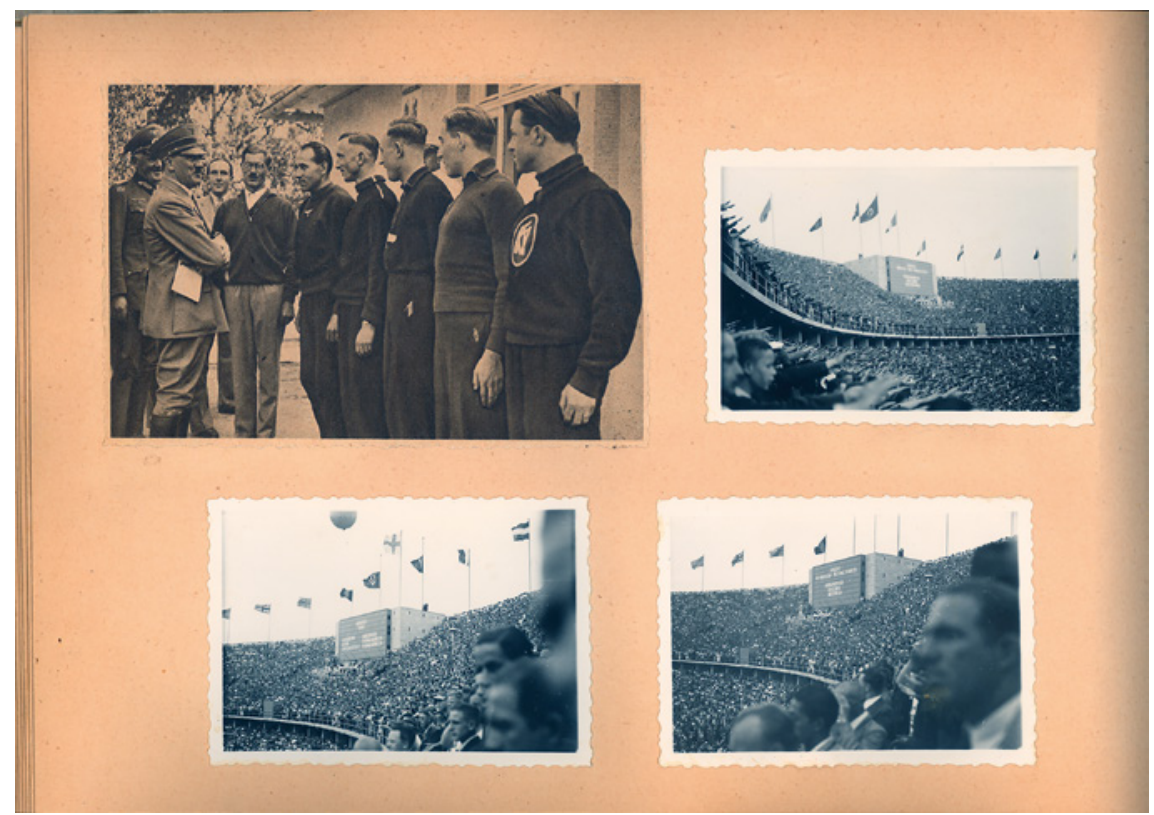

FIGURE 5.12 Page from album that has an imprint of Hitler with the German team and Mushabek at a game, 1936. Olympic Album, George Mushabek IMAGE COURTESY OF THE MUSHABEK FAMILY

Hitler's victory is a dangerous development for the Arabs in Palestine; his plans regarding the Jews are well known. He will not hesitate to realize these plans and we will witness waves of refugees to [Palestine]. The German Jews are rich industrials and they will be the first, who will take the land from our hands. ${ }^{17}$

The same sentiment was echoed by al-Difac, another Palestinian newspaper in 1936, the same year in which the as the Olympics were held, by stating that 'there will be no peace in Europe until the spirit of the Swastika, ruling Germany today, will be overcome.' ${ }^{18}$ It is, therefore, rather doubtful that the five visitors to Berlin were sympathetic to Nazism.

The visual travelogue, which is the album, starts with the departure of the friends from Jerusalem by train. They were local athletes, hailing from the

17 al-Jamāa a al-Islāmīyya, March 8, 1933, cited by René Wildangel's chapter entitled "More than the Mufti: Other Arab-Palestinian Voices on Nazi Germany, 1933-1945, and Their Postwar Narrations," in Arab Responses to Fascism and Nazism: Attraction and Repulsion, ed. Israel Gershoni (Austin: University of Texas Press, 2014), 108.

Cited in ibid., 108. 
Christian community of Palestine, at the Jerusalem YMCA, located on King George Street in the new section of the city. It was established in 1924 and the building was dedicated in 1933, a few years after the British High commissioner, Lord Plumer, laid the foundation stone in 1928. The five athletes won a grant to travel and attend the Olympics.

The first leg of the train trip was to Lydda (al-Lid) close to Jaffa, then another train took them to Haifa, from where they boarded a Greek ship towards Athens. At each stage, a snapshot was included in the album. It is possible that the photographs were placed in the album following its purchase in Berlin, as most images would be of the return journey, rather than its start, though the pictures are not organised starting from Berlin backwards. Several pictures were taken on board, including one with the ship's Greek captain and others with some of the passengers they befriended. Although, in one of the photographs, we see the friends wearing küfiyya, or the Arab headdress, we cannot be sure that this reflects a nationalist sentiment, though certainly it is an indication of identity. At the same time, the playfulness of some photographs in which the friends appear wearing not only the kūfiyya, but even the tarbush, or the Ottoman $f a \bar{s}$, could be seen as markers of class identity or acts of masquerade.

Upon arrival in Athens, the group visited its archaeological sites and took a number of snapshots before sailing to the Croatian port of Dubrovnik where they enjoyed a swim and the scenic port. They eventually arrived, one would imagine by train, to Berlin where they attended a number of games including handball, fuzzball and hockey. The tickets for the games were also included in the album.

Looking at this album from the standpoint of today, one cannot ignore the fact that it was simply an album of fun and leisure, something that nowadays never seems to emerge in all the studies about Palestine before 1948, including the increasingly popular nostalgia among Palestinians about the beautiful past'. This is an instance in which nothing can be found that indicates that the Palestinians were fighting colonialism or making fabulous achievements. Perhaps this is what makes this album so powerful if seen in the context of the politics of the loss of the homeland, for it is an album that illustrates that life in Palestine was rather normal, and the Palestinians were no different than any other people in the world.

\section{Conclusion}

The question that will no doubt surface following such a quick description of the albums relates to what is it that we can conclude from looking at these 


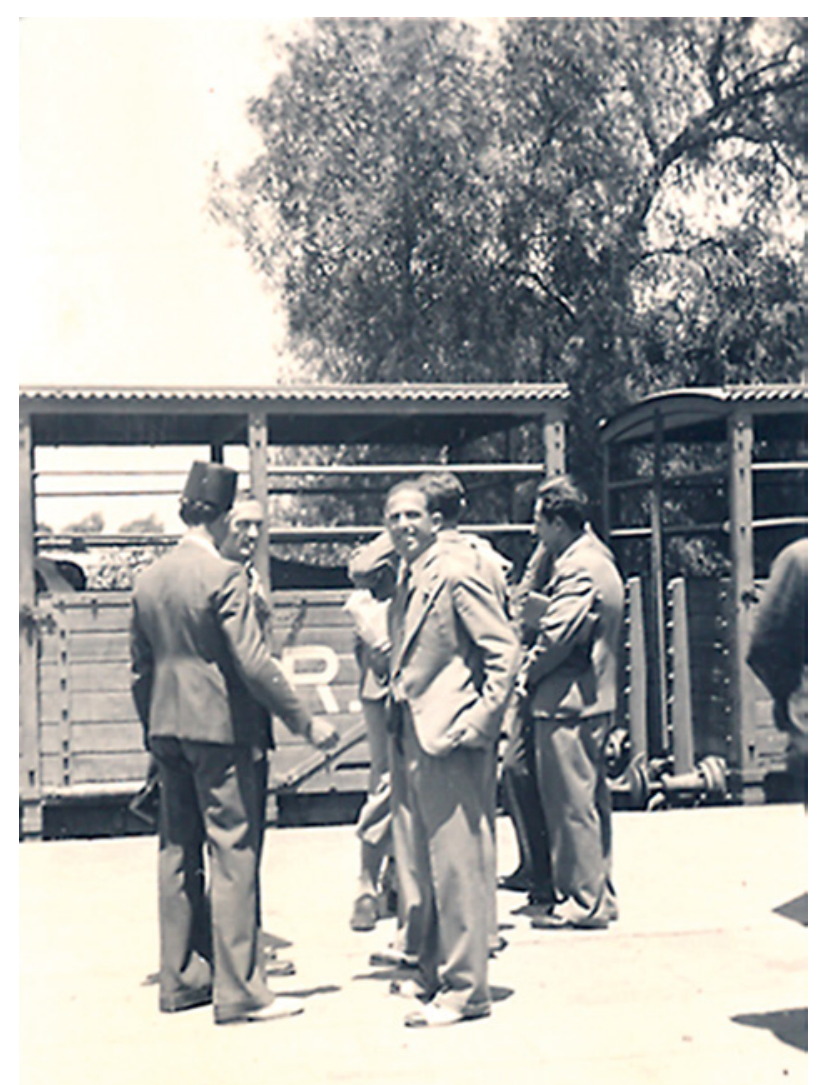

FIGURE 5.13 The friends at train station in Lydda during their return trip, 1936. Olympic Album,

George Mushabek

IMAGE COURTESY OF THE MUSHABEK FAMILY

albums together. To answer this, we need to return to the three observations with which the essay started, namely, the observations about Palestine and the Palestinians; about vernacular photography; and about photographic albums. Concluding with these questions, I would suggest a few reflections that could be a starting point for answers that I will need to further contemplate for future studies.

Starting with the theme of albums, this chapter attempts to make it clear that albums are rarely just collections of random pictures put together without serious consideration for their order. Rather they constitute both intentional visual narratives that recount an already envisioned narrative fashioned by their compilers, and archives in which photographs that were deemed 

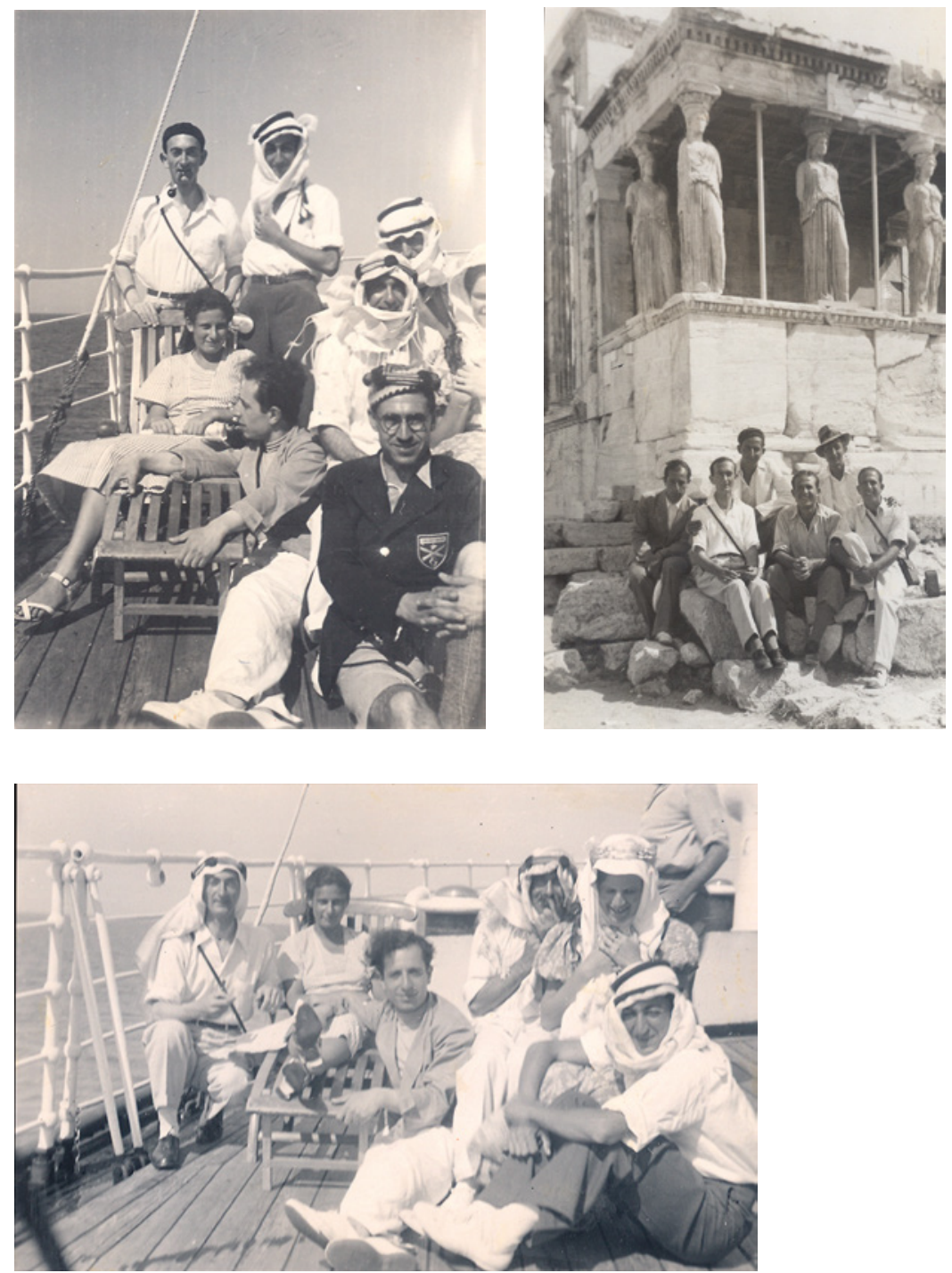

FIGURES 5.14-16 The friends onboard the Greek ship and visiting monuments in Greece. Olympic Album, George Mushabek IMAGE COURTESY OF THE MUSHABEK FAMILY

significant by the collector were preserved. The three albums under study illustrate these two points. For Jawharriyya, Luci, and Mushabek, their albums tell stories that are, in general, of private interest, and document the lives, or portions of them, of the individuals who assembled them. As such, they reflect both the single events depicted in each photograph, as well as visions that were 
intentionally offered to the viewer. This reflects not only certain issues about their authors and their aspirations, but about the society and the historical period in which they were produced as albums.

Similarly, vernacular photographs are significant in the study of the history of everyday life, as they capture people in settings less formal than the carefully planned professional studio portraits. They show people in moments of leisure that constitute part of their regular life, enabling social historians to unearth information about how life was at the time at which the photographs were captured.

As the photographs at hand are of Palestinian life, they provide us with immense amounts of information about ordinary middle-class life in Palestine before its destruction. They enable us to excavate lives that were marginalised by the dominant Palestinian national discourses of peasant hood and the land. Instead, they depict the life of the urban middle class. The very practice of collecting photographs in albums and the narratives those albums convey, affirm to us as viewers that life was, after all, normal in Palestine in many respects. People had 'normal' hopes and desires, conducting their lives not anticipating that their world was about to collapse. They provide us with the potential of a counter narrative that does not focus on violence but on normalcy, and opens up the possibility of exploring the variety of possible narratives about the history of Palestine, rather than just a single national discourse. At the same time, the albums and the photographs attest beyond doubt that, in the words of Mahmūd Darwīsh, Palestinians were once 'there, and they remember.'19

\section{Bibliography}

Edwards, Elizabeth. Raw Histories: Photographs, Anthropology and Museums. Oxford: Berg., 2001.

Gallop, Jane. "Observation of a Mother." In The Family Gaze, edited by Marianne Hirsch, 67-84. Dartmouth: University Press of New England, 1999.

Hammarberg, Gitta. "The First Russian Women's Journals and the Construction of the Reader." In Women in Russian Culture and Society, 1700-1825, edited by Wendy Rosslyn and Alessandra Tosi, 83-104. New York: Palgrave McMillan, 2007.

19 The poem by Darwish is entitled "I am There," and the reference is to the verse in the poem that says: I come from there and remember. The translation of the poem is available at: https://www.asmalldoseoftoxicology.org/voices-through-walls/2018/3/6/poem-i -am-there-by-mahmoud-darwish (accessed on December 31, 2019). 
Hirsch, Marianne. Family Frames:Photography, Narrative, and Postmemory. Cambridge: Harvard University Press, 1997.

Jawharriyyeh, Wasif. The Storyteller of Jerusalem: The Life and Times of Wasif Jawharriyyeh, edited by Salim Tamari and Issam Nassar. Northampton, MA: Interlink Publishing Group, 2014.

Musleh-Motut, Nawal. "From Palestine to the Canadian Diaspora: The Multiple Social Biographies of the Musleh Family's Photographic Archive." Middle East Journal of Culture and Communication 8 (2015): 307-326.

Nassar, Issam. "The Wasif Jawharriyyeh Collection: Illustrating Jerusalem during the First Half of the 2oth Century". In Ordinary Jerusalem, 1840-1940: Opening New Archives, Revisiting a Global City, edited by Angelos Dalachanis and Vincent Lemire, 385-398. Leiden: Brill, 2018.

Rose, Gillian. Doing Family Photography: The Domestic, The Public and The Politics of Sentiment. Rematerialising Cultural Geography. Kent, UK: Ashgate, 2010.

Seikaly, Sherene. Men of Capital: Scarcity and Economy in Mandate Palestine. Stanford: Stanford University Press, 2016.

Toxipedia. "Poem "I Am There" by Mahmoud Darwish." Accessed December 31, 2019. https://www.asmalldoseoftoxicology.org/voices-through-walls/2018/3/6/poem -i-am-there-by-mahmoud-darwish.

Wildangel, René. "More than the Mufti: Other Arab-Palestinian Voices on Nazi Germany, 1933-1945, and Their Postwar Narrations." In Arab Responses to Fascism and Nazism: Attraction and Repulsion, edited by Israel Gershoni, 101-126. Austin: University of Texas Press, 2014. 